\title{
CONTROL OF AFLATOXIGENIC Aspergillus flavus IN PEANUTS USING NONAFLATOXIGENIC A. flavus, A. niger and Trichoderma harzianum
}

\author{
OKKY SETYAWATI DHARMAPUTRA \\ SEAMEO BIOTROP, P.O. Box 116, Bogor, Indonesia and \\ Faculty of Mathematics and Natural Sciences, Bogor Agricultural University, Bogor, \\ Indonesia \\ ASMARINA S.R. PUTRI, INA RETNOWATI and SANTIAMBARWATI \\ SEAMEO BIOTROP, P.O. Box 116, Bogor, Indonesia
}

\begin{abstract}
The effects of nontoxigenic Aspergillus flavus, A. niger and Trichoderma harzianum inoculated into planting media on toxigenic $A$. flavus infection and its aflatoxin production in peanut kernels at harvest were investigated together with (1) the moisture content of planting media before peanut planting, at the time of inflorescence, and at harvest, (2) the population of aflatoxigenic and nonaflatoxigenic A. flavus, A. niger and T. harzianum in peanut planting media before peanut planting, at the time of inflorescence, and at harvest, (3) the moisture content of peanut kernels at harvest, and (4) toxigenic A. flavus invasion in peanut plant parts (roots, stems, petioles, leaves and flowers) at the time of inflorescence.

The fungal isolates were inoculated into planting media at the same time with the planting of peanut seeds. Peanut plants were grown under glasshouse conditions. Treated planting media were inoculated with the combined use of (1) toxigenic and nontoxigenic A. flavus, (2) toxigenic A. flavus and A. niger, and (3) toxigenic A. flavus and T. harzianum. Planting media inoculated only with each fungal isolate and uninoculated planting media were used as controls. Two watering treatments of peanut plants were carried out, i.e. watering until harvest and not watering for 15 days before harvest. The populations of the fungal isolates in the planting media and peanut kernels were determined using dilution method followed by pour plate method; the percentages of toxigenic A. flavus and test fungal colonizations in peanut plant parts were determined using plating method; the moisture content of planting media and peanut kernels were determined using oven method; the aflatoxin content of peanut kernels was determined using Thin Layer Chromatography method.

The results indicated that at the time of harvest the decrease in moisture contents of planting media not watered for 15 days before harvest was higher than those watered until harvest. The lowest population of toxigenic $A$. flavus was in planting media inoculated with the combined use of toxigenic and nontoxigenic $A$. flavus at the time of inflorescence and at the time of harvest. Toxigenic A. flavus could invade the roots, stems and flowers of peanut plants. The lowest percentage of invasion was on the plant parts which planting media were inoculated with the combined use of toxigenic and nontoxigenic A. flavus. The moisture content of peanut kernels originated from watered plants until harvest were higher than those not watered for 15 days before harvest. The population of toxigenic A. flavus in peanut kernels derived from the plants whose planting media were inoculated with the combined use of toxigenic $A$. flavus and each test fungi, was lower than those inoculated only with toxigenic $A$. flavus. It indicated that the test fungi inoculated into planting media could inhibit toxigenic A. flavus infection in peanut kernels. Aflatoxin was only detected in peanut kernels originated from one plant whose planting medium was inoculated only with toxigenic $A$. flavus and the plant was watered until the time of harvest. Toxigenic $A$. flavus infection and aflatoxin production were not influenced by planting media which were not watered for 15 days before harvest.
\end{abstract}

Keywords: Biocontrol / Aflatoxigenic / Nonaflatoxigenic / Aspergillus flavus I Aspergillus niger I Trichoderma harzianum I Peanuts 


\section{INTRODUCTION}

Aflatoxins are potential hepatotoxic and carcinogenic metabolites produced by the fungi Aspergillus flavus, A. parasiticus, and A. nomius. Contamination of afla-toxins occurs when peanut kernels become infected by the three fungal species under drought stress before harvest, during the drying phase in the field, or under unsuitable storage conditions.

Pitt and Hocking (1996) reported that 45, 33 and 22\% of 215 peanut samples collected from farm storage, middlemen and retailers in Bogor and Yogyakarta contained aflatoxins of more than 50, 300 and $1000 \mathrm{ppb}$, respectively. Levels of $1000 \mathrm{ppb}$ of aflatoxins will cause liver damage in man and animals. Lower levels of aflatoxins consumed from peanut products can cause liver cancer and premature death in humans, as well as reducing productivity of livestock. Based on the report of the $23^{\text {rd }}$ Session of the Joint FAOAVHO Food Standards Programme, held in Rome, Italy, 28 June - 3 July 1999, Codex Alimentarius Commissions adopted 15 ppb as the maximum level of total aflatoxins to be contained in peanuts intended for further processing.

The entry of aflatoxin in the peanut plant could be from the roots, flowers, leaves damaged by insects, and from air or dust. The most important point of entry to the developing peanut, however, is directly from the soil surrounding it. So, the point of application of any biocontrol measure such as competitive exclusion should be in the soil of peanut - growing fields.

There are only few reports on the reduction of aflatoxins by competitive fungi. Ehrlich et al. (1985) reported that by growing A. parasiticus in mixed culture with Penicillium oxalicum, toxin productions of both species were reduced. To assess this effect under more practical conditions, Wicklow et al. (1988) inoculated corn kernels with toxigenic A. flavus at preharvest, with or without a range of other fungi present. They found that much lower levels of preharvest aflatoxin were produced in the presence of some other fungal species. Dorner et al. (1999) found that aflatoxin contamination of corn was reduced when the soil of corn plots were inoculated with nonaflatoxigenic strain of $A$. flavus. Dharmaputra et al. (2001) reported that non-aflatoxigenic $A$. flavus BIO 2127, A. niger BIO 2129 and Trichoderma harzianum BIO 19130 were antagonistic to aflatoxigenic A. flavus BIO 2128 in vitro. Aspergillus niger was the most promising fungal antagonist, because it caused the highest percent inhibition of aflatoxin production of A. flavus BIO 2128.

The objectives of this study were to investigate the effects of nontoxigenic A. flavus, A. niger and $T$. harzianum inoculated into the peanut planting media on toxigenic $A$. flavus infection and its aflatoxin production in peanut kernels at harvest. Investigations were also carried out on (1) the moisture contents of planting media before peanut planting, at the time of inflorescence, and at harvest, (2) the population of aflatoxigenic and nonaflatoxigenic A. flavus, A. niger and $T$. harzianum in peanut planting media before peanut planting, at the time of inflorescence and at harvest, (3) the moisture content of peanut kernels at the time of harvest, and (4) toxigenic $A$. flavus invasion in peanut plant parts (roots, stems, petioles, leaves and flowers) at the time of inflorescence. 
Control of aflatoxigenic Aspergillus flavus In peanuts - Okky S. Dharmaputra et al.

\section{MATERIALS AND METHODS}

\section{Planting media, peanut variety, isolates of toxigenic $A$. flavus and test fungi}

A mixture of soil (latosol type), sand and casting (2:1:1) was used as planting medium, while peanut variety Komodo was obtained from the Research Institute for Legumes and Tuber Crops (RILET) in Malang. Four fungal isolates were used: toxigenic A. flavus BIO 2128, nontoxigenic A. flavus BIO 2127, A. niger BIO 2129, and T. harzianum BIO 19130. The latter three fungal isolates were used as test fungi.

\section{Preparation of A. flavus, A. niger and T. harzianum inocula}

Mixtures of ground rice bran and tap water (4:3) were placed in transparent polyethylene bags (125 g/bag). They were then sterilized in an autoclave for $1 \mathrm{~h}$, and incubated at room temperature for one night. For the time being, each fungal isolate was grown on Potato Dextrose Agar in Petri dishes (diam $9 \mathrm{~cm}$ ) and incubated at room temperature for 6 days. Five $\mathrm{ml}$ of spore suspension $\left(10^{6}\right.$ spores $\left./ \mathrm{ml}\right)$ of each fungal isolate was inoculated into the mixture of sterilized ground rice bran and tap water. They were then incubated at room temperature for 7 days to obtain the inocula of planting media.

\section{Inoculation of toxigenic $A$. flavus and test fungi into planting media, and seed planting}

Pasteurized planting media were placed in black polyethylene bags (15 kg/bag). The inocula of planting media were then mixed with planting media at the time of germinated-seed planting (1 seed^ag).

Treated planting media were inoculated with the combined use of (1) toxigenic and nontoxigenic A. flavus, (2) toxigenic A. flavus and A. niger, (3) toxigenic A. flavus and $T$. harzianum. The comparison of toxigenic $A$. flavus and each test fungal isolate was 1:1 (one portion was equivalent with $30 \mathrm{~g}$ of inoculum). Planting media inoculated only with each fungal isolate and uninoculated planting media were used as controls. Six replicates (6 bags) were used for each treatment (including the controls). The bags with the peanut plants were placed under greenhouse conditions.

Two watering treatments of peanut plants were carried out, i.e. (1) watering until harvest and (2) not watering for 15 days before harvest. Sterilized tap water was used for watering peanut plants. The individual plants were watered with the same volumes of sterilized tap water.

\section{Sampling of planting media}

Sampling of planting media were conducted :

Before peanut-seed planting, but after each treated planting medium as well as each control (except uninoculated planting media) have been mixed with fungal 
inocula homogeneously. They were then placed in clean polyethylene bags (about 1 $\mathrm{kg} / \mathrm{bag} /$ treatment or control).

- At the time of inflorescence and at the time of harvest. The peanut plants were pulled prior to sampling of planting media. Each treated planting medium as well as each control was mixed homogeneously; they were then placed in clean polyethylene bags (about $1 \mathrm{~kg} / \mathrm{bag} /$ treatment or control).

Each sample of planting media (about $1 \mathrm{~kg}$ ) was divided several times manually to obtain working samples for moisture content and fungal analysis, and for reserved sample.

Determination of moisture contents of planting media; population of toxigenic A. flavus and test fungi in planting media before peanut seed planting, at the time of inflorescence and at the time of harvest

Moisture content of planting media derived from each bag was determined using oven method at $105^{\circ} \mathrm{C}$ for 12 hours (Johnson et al. 1960). The population of each fungal isolate in planting media before peanut seed planting, at the time of inflorescence and at the time of harvest was determined using serial dilution method, followed by pour plate method (Johnson and Curl 1972) on PDA containing chloramphenicol (100 mg/L media).

\section{Sampling of peanut plants at the time of inflorescence}

At the time of inflorescence (25 - 30 days after planting), peanut plants grown on treated planting media as well as on the controls, were pulled. Their roots, stems, petioles, leaves and flowers were then cut into pieces (10 pieces/plant) about $1 \mathrm{~cm}$ long, surface sterilized using $0.5 \%$ Na-hypochloride for one minute, rinsed with sterile distilled water, dried on sterilized filter paper, and finally plated on Potato Dextrose Agar (PDA) containing chloramphenicol (100 mg/L media). The percentage of each fungal isolate colonization in various plant parts was determined using the following formula:

\begin{tabular}{lll}
\cline { 2 - 2 } & \multicolumn{1}{c}{ Number of plant part pieces } \\
plant part pieces Colonized & Colonized by each fungal isolate & \\
by each fungal isolate & Number of plant part pieces & \\
& plated on agar media
\end{tabular}

Determination of moisture content of peanut kernels; population of toxigenic $A$. flavus and test fungi, and aflatoxin content in peanut kernels

Peanuts were harvested at 90 days after planting. They were then shelled manually and aseptically. Peanut kernels derived from treated planting media and 
the controls were divided using a box sample divider to obtain working samples for moisture content, fungal and aflatoxin analyses. The moisture content of peanut kernels was determined using the oven method (BSI 1995). The population of toxigenic A. flavus and test fungi was determined using serial dilution method, followed by pour plate method on PDA containing chloramphenicol (100 mg/L media). Aflatoxin content in peanut kernels was determined using Thin Layer Chromatography method'(AO AC 1995).

\section{Statistical analyses}

The experimental design used in this study was Completely Randomized Factorial Design with two factors, i.e. the kind of fungal inocula in planting media and watering of peanut plants. The kinds of fungal inocula consisted of (1) the combined use of toxigenic and nontoxigenic A. flavus, (2) toxigenic A. flavus and A. niger, (3) toxigenic A. flavus and $T$. harzianum, (4) toxigenic A. flavus, (5) nontoxigenic A. flavus, (6) A. niger, (7) T. harzianum, and (8) uninoculated planting media.-Peanut plants (1) were watered until harvest and (2) not watered for 15 days before harvest.

\section{RESULTS AND DISCUSSION}

\section{Moisture content of planting media before peanut seed planting, at the time of inflorescence and harvest}

The fungal inocula did not give any significant difference on the moisture contents of planting media at the time of inflorescence. Besides, the moisture contents of planting media before peanut planting were not significantly different from the time of inflorescence. It indicated that up to the time of inflorescence, the moisture contents of planting media were always stable, although the media were inoculated with various fungal inocula.

The moisture content of planting media treated with various fungal inocula and the time of watering decreased from before peanut planting up to harvest. Fungal inocula and their interaction with time of watering were not significantly different with the decrease of moisture contents, while time of watering showed significant differences.

Table 1 shows that the decrease in moisture content of planting media not watered for 15 days before harvest (22.9\%) was higher than that watered until harvest (11.1\%). 
BIOTROPIA NO. 21,2003

Table 1. The decrease in moisture content of planting media before peanut planting until harvest time

\begin{tabular}{cc}
\hline \hline Treatment & Decrease of moisture content (\%) \\
\hline \hline Watered planting media & $11.09 \mathrm{a}$ \\
Not watered planting media & $22.85 \mathrm{~b}$ \\
\hline
\end{tabular}

Numbers followed by the same letter do not differ significantly according to Duncan Multiple Range Test at 95\% confidence level Population of toxigenic $A$. flavus and test fungi in planting media before peanut planting, at the
time of inflorescence and at the time of harvest

In the planting media, populations of toxigenic A. flavus and test fungi in-creaseed at the time of inflorescence as well as at the time of harvest. At the time of inflorescence, fungal inocula gave significant differences on the increase of toxigenic $A$. flavus and test fungal populations. At the time of harvest, fungal inocula and time of watering gave significant differences on the increase of fungal populations.

The increase of toxigenic A. flavus population in planting media inoculated with the combined use of toxigenic and nontoxigenic $A$. flavus was lower compared with planting media inoculated (1) only with toxigenic A. flavus, (2) with the combined use of toxigenic $A$. flavus and $A$. niger, and (3) with the combined use of toxigenic A. flavus and T. harzianum, either at the time of inflorescence or at the time of harvest (Table 2).

The increase of each test fungal population in either the planting media inoculated with each test fungi or in the planting media inoculated with the combined use of toxigenic $A$. flavus and each test fungi were higher than the increase of toxigenic $A$. flavus population in the planting media inoculated only with toxigenic A. flavus and in the planting media inoculated with the combined use of toxigenic $A$. flavus and test fungi, either at the time of inflorescence or at the time of harvest (Table 2). It indicated' that the growth of toxigenic A. flavus was more inhibited compared with the growth of test fungi, either in the planting media inoculated with each fungal isolate or in the planting media inoculated with the combined use of toxigenic $A$. flavus and test fungi.

At the time of harvest, the increase of fungal population in the watered planting media was higher than that not watered for 15 days before harvest (Table 3). It was related to the decrease of moisture content which was higher in the not watered planting media compared with the watered planting media (Table 1), consequently fungal growth was inhibited. 
Table 2. The increase of toxigenic Aspergillus flavus and test fungal populations in the planting media inoculated with various inocula at the time of inflorescence and harvest

\begin{tabular}{|c|c|c|c|c|}
\hline \multirow{3}{*}{$\begin{array}{c}\text { Fungal inocula } \\
\text { in the planting media }\end{array}$} & \multicolumn{4}{|c|}{ Increase of fungal population (cfu/g dry weight) } \\
\hline & \multirow[b]{2}{*}{ Fungi } & \multirow{2}{*}{$\begin{array}{l}\text { At the time of } \\
\text { inflorescence }\end{array}$} & \multicolumn{2}{|c|}{ At the time of harvest } \\
\hline & & & $\begin{array}{l}\text { Transformed } \\
\text { into } \log x\end{array}$ & $\begin{array}{c}\text { Not } \\
\text { transformed }\end{array}$ \\
\hline Toxigenic Aspergillus flavus & Toxigenic $A$. flavus & $362214 \mathrm{ab}$ & $4.6421 \mathrm{ab}$ & 53655 \\
\hline $\begin{array}{l}\text { Toxigenic } A . \text { flavus vs } \\
\text { nontoxigenic } A \text {. flavus }\end{array}$ & Toxigenic A. flavus & 282333 a & $4.4666 \mathrm{a}$ & 39727 \\
\hline Toxigenic $A$. flavus vs $A$. niger & Toxigenic $A$. flavus & $513562 \mathrm{ab}$ & $4.8380 \mathrm{~b}$ & 115011 \\
\hline $\begin{array}{l}\text { Toxigenic } A \text {. flavus vs } \\
\text { Trichoderma harzianum }\end{array}$ & Toxigenic $A$. flavus & $624964 \mathrm{ab}$ & $4.6148 \mathrm{ab}$ & 51481 \\
\hline Nontoxigenic $A$. flavus & Nontoxigenic A. flavus & $1533069 \mathrm{~b}$ & $5.7928 \mathrm{~cd}$ & 694390 \\
\hline $\begin{array}{l}\text { Toxigenic } A \text {. flavus vs } \\
\text { nontoxigenic } A \text {. flavus }\end{array}$ & Nontoxigenic $A$. flavus & $3838215 \mathrm{c}$ & $5.6359 \mathrm{c}$ & 619960 \\
\hline A. niger & A. niger & $2955578 \mathrm{c}$ & $5.9010 \mathrm{~cd}$ & 1024393 \\
\hline Toxigenic $A$. flavus vs $A$. niger & A. niger & $3809040 \mathrm{c}$ & $6.0054 \mathrm{~d}$ & 1135405 \\
\hline T. harzianum & T. harzianum & $1385558 \mathrm{ab}$ & $5.8040 \mathrm{~cd}$ & 807209 \\
\hline $\begin{array}{l}\text { Toxigenic } A \text {. flavus vs. } \\
\text { T. harzianum }\end{array}$ & T. harzianum & $1294316 \mathrm{ab}$ & $5.6993 \mathrm{~cd}$ & 852893 \\
\hline
\end{tabular}

Numbers followed by the same letter in the same column do not differ significantly according to Duncan Multiple Range Test at $95 \%$ confidence level

Table 3. The increase of fungal population in watered and not watered planting media at harvest time

\begin{tabular}{lcc}
\hline \multirow{2}{*}{ Treatment } & \multicolumn{2}{c}{ Increase of fungal population (cfu/g dry weight) } \\
\cline { 2 - 3 } & Transformed into $\log \mathrm{x}$ & Not transformed \\
\hline Watered planting media & $5.4753 \mathrm{a}$ & 697710 \\
Not watered planting media & $5.2047 \mathrm{~b}$ & 381114 \\
\hline
\end{tabular}

Numbers followed by the same letter do not differ significantly according to Duncan Multiple Range Test at $95 \%$ confidence level

At the time of harvest in the uninoculated planting media, three fungal isolates were found: nontoxigenic A. flavus, Cladosporium cladosporioides and T. harzianum. It was assumed that fungal contamination originated from the air or from peanut seeds. 


\section{Toxigenic A. flavus and test fungal invasion in peanut plants at the time of inflorescence}

Pitt et al. (1991) stated that the invasion of toxigenic A. flavus in peanut plants could originate from the soils or from peanut seeds grown under greenhouse conditions.

Toxigenic A. flavus invasion was observed in peanut plants where the planting media were inoculated with the fungus as well as its combination with the test fungi (Table 4). Its percentage of invasion occurring in plant parts adjacent to the soils (root and stem) was higher than the other parts (petioles and leaves). Pitt et al. (1991) reported that A. flavus could invade all plant parts, with the highest invasion occurring in plant parts adjacent to the soils.

The percentage of toxigenic $A$. flavus invasion in plants where the planting media were inoculated with the combined use of toxigenic and nontoxigenic $A$. flavus, toxigenic $A$. flavus and $A$. niger was lower than that only inoculated with toxigenic $A$. flavus. Nevertheless, the percentage of toxigenic $A$. flavus invasion was higher in plants where the planting media were inoculated with the combined use of the fungus and $T$. harzianum (Table 4). In the planting media inoculated with the combined use of toxigenic $A$. flavus and nontoxigenic A. flavus, also the combined use of toxigenic A. flavus and A. niger, the invasion of toxigenic A. flavus were only in the roots, while in the planting media inoculated only with toxigenic A. flavus, this fungus could invade roots, stems and flowers. In the planting media inoculated with toxigenic A. flavus and T. harzianum, toxigenic A. flavus could invade all the plant parts. The percentage of toxigenic $A$. flavus invasions was related to the increase of toxigenic A. flavus population in the planting media (Table 2). The lowest increase of toxigenic A. flavus population was in the planting media inoculated with the combined use of toxigenic and nontoxigenic $A$. flavus, while the highest was in the planting media inoculated with the combined use of toxigenic $A$. flavus and T. harzianum.

In the planting media inoculated only with toxigenic $A$. flavus as well as those inoculated with the combined use of toxigenic A. flavus and T. harzianum, toxigenic A. flavus could also invade flowers (Table 4). It is related to the position of peanut flowers, i.e. adjacent to the planting media. If the flowers come in contact with the planting media, they could be invaded by toxigenic A. flavus.

Toxigenic A. flavus derived from the planting media can systemically invade peanut plant parts adjacent to the soil up to the plant parts above the soil surface. The fungus can also invade young peanut plants.

Based on microscopic examination, little or no damage was observed in the cells of stems invaded by A. flavus (Pitt et al. 1991). Toxigenic A. flavus invasion did not cause any disease in peanut plants. 
Table 4. The percentage of plant parts colonized by toxigenic Aspergillus flavus and test fungi at the time of inflorescence

\begin{tabular}{|c|c|c|c|c|c|c|c|}
\hline \multirow{2}{*}{$\begin{array}{c}\text { Fungal inocula } \\
\text { in planting } \\
\text { media }\end{array}$} & \multirow{2}{*}{ Fungi } & \multicolumn{5}{|c|}{ Plant parts colonized by fungi $(\%)$} & \multirow{2}{*}{ Remark } \\
\hline & & Root & Stem & Petiole & Leaf & Flower & \\
\hline \multirow[t]{6}{*}{ Uninoculated } & $\begin{array}{l}\text { Toxigenic } \\
\text { A. flavus }\end{array}$ & 0 & 8.3 & 0 & 0 & 0 & \multirow{6}{*}{$\begin{array}{l}\text { It was assumed that } \\
\text { fungal contamination } \\
\text { originated from air } \\
\text { or seeds }\end{array}$} \\
\hline & $\begin{array}{l}\text { Nontoxigenic } \\
\text { A. flavus }\end{array}$ & 6.6 & 18.3 & 0 & 0 & 5 & \\
\hline & A. niger & 10 & 0 & 10 & 0 & 8.7 & \\
\hline & Fusarium sp. & 13.3 & 0 & 0 & 0 & 0 & \\
\hline & Gilmaniella sp. & 0 & 15 & 0 & 0 & 0 & \\
\hline & Nigrospora sp. & 0 & 0 & 0 & 6.6 & 0 & \\
\hline $\begin{array}{l}\text { Toxigenic } A \text {. } \\
\text { flavus }\end{array}$ & $\begin{array}{l}\text { Toxigenic } \\
\text { A. flavus }\end{array}$ & $10^{*}$ & 18.3 & 0 & 0 & 5 & $\begin{array}{l}\text { * Contaminated by } \\
\text { Fusarium } \text { sp. } \\
(31.6 \%)\end{array}$ \\
\hline $\begin{array}{l}\text { Nontoxigenic } \\
\text { A. flavus }\end{array}$ & $\begin{array}{l}\text { Nontoxigenic } \\
\text { A. flavus }\end{array}$ & 26.6 & 43.3 & $0^{*}$ & $0 *$ & 16.6 & $\begin{array}{l}\text { * Contaminated by } \\
\text { Nigrospora } \text { sp. } \\
(8.3 \%)\end{array}$ \\
\hline A. niger & A. niger & 56.6 & 60 & 43.3 & 23.3 & 51.6 & $\begin{array}{l}\text { All plant parts were } \\
\text { contaminated by } \\
\text { Fusarium sp. }(85 \%)\end{array}$ \\
\hline $\begin{array}{l}\text { Trichoderma } \\
\text { harzianum }\end{array}$ & T. harzianum & 46.6 & 10 & 3.3 & 0 & 0 & \\
\hline \multirow{2}{*}{$\begin{array}{l}\text { Toxigenic } A \text {. } \\
\text { flavus vs } \\
\text { nontoxigenic } \\
\text { A. flavus }\end{array}$} & $\begin{array}{l}\text { Toxigenic } \\
\text { A. flavus }\end{array}$ & $3.3^{*}$ & 0 & 0 & 0 & 0 & \multirow{2}{*}{$\begin{array}{l}\text { * Contaminated by } \\
\text { Fusarium solani } \\
(33.3 \%) \\
\text { * Contaminated by } \\
\text { Fusarium } \mathrm{sp} .(8.3 \%)\end{array}$} \\
\hline & $\begin{array}{l}\text { Nontoxigenic } \\
\text { A. flavus }\end{array}$ & 68.3 & $40^{*}$ & 6.6 & 0 & 22.5 & \\
\hline \multirow[t]{2}{*}{$\begin{array}{l}\text { Toxigenic } A \text {. } \\
\text { flavus vs } A \text {. } \\
\text { niger }\end{array}$} & $\begin{array}{l}\text { Toxigenic } \\
\text { A. flavus }\end{array}$ & $1.6^{*}$ & 0 & 0 & 0 & 0 & \multirow{2}{*}{$\begin{array}{l}\text { * Contaminated by } \\
\text { Sphaeropsis } \text { sp. } \\
(20 \%)\end{array}$} \\
\hline & A. niger & 21.6 & 16.6 & 8.3 & 10 & 6.8 & \\
\hline \multirow[t]{2}{*}{$\begin{array}{l}\text { Toxigenic } A \text {. } \\
\text { flavus } \text { vs } T \text {. } \\
\text { harzianum }\end{array}$} & $\begin{array}{l}\text { Toxigenic } \\
\text { A. flavus }\end{array}$ & 16.6 & 21.6 & 5 & 9.1 & $11.6^{*}$ & \multirow{2}{*}{$\begin{array}{l}\text { * Contaminated by } \\
\text { Exosporium sp. } \\
(16.6 \%) \text { and } \\
\text { Tubercularia } \mathrm{sp} \text {. } \\
(8.3 \%)\end{array}$} \\
\hline & T. harzianum & 20 & 13.3 & 5 & 3.3 & 0 & \\
\hline
\end{tabular}

Test fungi could also colonize roots, stems, petioles, leaves and flowers (Table 4). Some plant parts, either on planting media inoculated with toxigenic A. flavus, test fungi, or uninoculated planting media, were contaminated with other fungi such as Exosporium sp., Fusarium spp., Gilmaniella spp., Sphaeropsis sp. and Tuber- 
cularia sp. (Table 4). It was assumed that the fungal contamination originated from the air or peanut seeds.

\section{Moisture content of peanut kernels at the time of harvest}

The fungal inocula and their interaction with time of watering did not give any significant difference on the moisture content of peanut kernels at the time of harvest, while only time of watering gave significant differences. The moisture content of peanut kernels derived from watered plants until harvest was higher than those of not watered plants for 15 days before harvest (Table 5).

Table 5. Moisture content of peanut kernels in watered and not watered planting media at harvest time

\begin{tabular}{cc}
\hline \hline Treatment & Moisture content (\%) \\
\hline Watered planting media & $38.38 \mathrm{a}$ \\
Not watered planting media & $33.58 \mathrm{~b}$ \\
\hline
\end{tabular}

Numbers followed by the same letter do not differ significantly according to Duncan Multiple Range Test at $95 \%$ confidence level

The effects of nontoxigenic $A$. flavus, $A$. niger and T. hanianum on toxigenic $A$. flavus infection and aflatoxin production in peanut kernels

From six replications derived from the planting media inoculated with toxigenic A. flavus and its combination with test fungi, in general only one replication of peanut kernels was infected by the fungus (Table 6). It indicated that the capability of toxigenic A. flavus in infecting peanut kernels was relatively low.

Toxigenic A. flavus population in peanut kernels derived from the plants where the planting media were inoculated with the combination of toxigenic $A$. flavus and each test fungal isolate was lower than that of only inoculated with toxigenic A. flavus (Table 6). It indicated that the test fungal isolates inoculated into planting media could inhibit toxigenic A. flavus infection in peanut kernels.

Aflatoxin was only detected in peanut kernels derived from the plants where the planting media were only inoculated with toxigenic A. flavus and the plants were always watered until harvest time. Aflatoxin B] was produced with a concentration of $32 \mathrm{ppb}$ (Table 7). It indicated that toxigenic A. flavus (21 cfu/g dry weight) in peanut kernels (Table 6) could produce aflatoxin.

Aflatoxin was not detected in peanut kernels derived from the plants where the planting media were inoculated with a combination of toxigenic A. flavus and test fungi, either in watered plants or unwatered plants for 15 days before harvest, because the test fungi could inhibit aflatoxin production of toxigenic A. flavus. Inhibition of aflatoxin production caused by the test fungi could be affected by the 
Control of aflatoxigenic Aspergillus flavus in peanuts - Okky S. Dharmaputra et al.

dose of biocontrol agent inocula. According to Dorner et al. (1998), aflatoxin production in peanut kernels decreased with the increase of the dose of biocontrol agents inocula (nontoxigenic $A$. flavus and A. parasiticus) inoculated into the soils. Aflatoxin content in peanut kernels with the dose of biocontrol agents inocula 0, 2, 10 and $50 \mathrm{~g} / \mathrm{m}$ were 337.6, 73.7, 34.8 and $33.3 \mathrm{ppb}$, respectively.

Table 6. Toxigenic Aspergillus flavus and test fungal populations in peanut kernels at harvest *)

\begin{tabular}{|c|c|c|c|c|c|c|c|}
\hline \multirow{3}{*}{$\begin{array}{l}\text { Fungal inocula and } \\
\text { time of watering }\end{array}$} & \multicolumn{7}{|c|}{ Fungal population (cfu/g dry weight) } \\
\hline & \multirow{2}{*}{ Fungi } & \multicolumn{6}{|c|}{ Replication } \\
\hline & & 1 & 2 & 3 & 4 & 5 & 6 \\
\hline Toxigenic $A$. flavus - watered & Toxigenic $A$. flavus & 0 & 21 & 0 & 0 & 0 & 0 \\
\hline $\begin{array}{l}\text { Toxigenic } A \text {. flavus-not } \\
\text { watered }\end{array}$ & Toxigenic A. flavus & 0 & 0 & 0 & 0 & 0 & 0 \\
\hline $\begin{array}{l}\text { Nontoxigenic A. flavus - } \\
\text { watered }\end{array}$ & Nontoxigenic $A$. flavus & 0 & 0 & 0 & 0 & 0 & 0 \\
\hline $\begin{array}{l}\text { Nontoxigenic } A \text {. flavus - not } \\
\text { watered }\end{array}$ & Nontoxigenic A. flavus & 0 & 0 & 0 & 0 & 0 & 0 \\
\hline A. niger - watered & A. niger & 0 & 0 & 0 & 0 & 0 & 0 \\
\hline A. niger - not watered & A. niger & 0 & 0 & 0 & 4 & 0 & 0 \\
\hline T. harzianum - watered & T. harzianum & 26 & 0 & 0 & 30 & 0 & 0 \\
\hline T. harzianum - not watered & T. harzianum & 0 & 0 & 0 & 0 & 0 & 0 \\
\hline $\begin{array}{l}\text { Toxigenic } A . \text { flavus vs } \\
\text { nontoxigenic } A . \text { flavus - } \\
\text { watered }\end{array}$ & $\begin{array}{l}\text { Toxigenic } A \text {. flavus } \\
\text { Nontoxigenic A.flavus }\end{array}$ & $\begin{array}{c}10 \\
0\end{array}$ & $\begin{array}{l}0 \\
0\end{array}$ & $\begin{array}{l}0 \\
0\end{array}$ & $\begin{array}{l}0 \\
0\end{array}$ & $\begin{array}{l}0 \\
0\end{array}$ & $\begin{array}{l}0 \\
0\end{array}$ \\
\hline $\begin{array}{l}\text { Toxigenic } A \text {. flavus vs } \\
\text { nontoxigenic } A \text {. flavus - not } \\
\text { watered }\end{array}$ & $\begin{array}{l}\text { Toxigenic A. flavus } \\
\text { Nontoxigenic A.flavus }\end{array}$ & $\begin{array}{l}0 \\
0\end{array}$ & $\begin{array}{l}0 \\
0\end{array}$ & $\begin{array}{c}0 \\
10\end{array}$ & $\begin{array}{l}0 \\
0\end{array}$ & $\begin{array}{l}0 \\
0\end{array}$ & $\begin{array}{l}0 \\
0\end{array}$ \\
\hline $\begin{array}{l}\text { Toxigenic } A \text {. flavus vs } \\
\text { A. niger - watered }\end{array}$ & $\begin{array}{l}\text { Toxigenic } A \text {. flavus } \\
\text { A. niger }\end{array}$ & $\begin{array}{l}0 \\
0\end{array}$ & $\begin{array}{l}0 \\
0\end{array}$ & $\begin{array}{l}0 \\
0\end{array}$ & $\begin{array}{l}0 \\
0\end{array}$ & $\begin{array}{l}0 \\
0\end{array}$ & $\begin{array}{l}0 \\
6\end{array}$ \\
\hline $\begin{array}{l}\text { Toxigenic A. flavus vs } \\
\text { A. niger - not watered }\end{array}$ & $\begin{array}{l}\text { Toxigenic } A \text {. flavus } \\
\text { A. niger }\end{array}$ & $\begin{array}{l}10 \\
72\end{array}$ & $\begin{array}{l}0 \\
0\end{array}$ & $\begin{array}{l}0 \\
0\end{array}$ & $\begin{array}{c}0 \\
53\end{array}$ & $\begin{array}{l}0 \\
0\end{array}$ & $\begin{array}{l}0 \\
0\end{array}$ \\
\hline $\begin{array}{l}\text { Toxigenic } A \text {. flavus vs } \\
\text { T. harzianum - watered }\end{array}$ & $\begin{array}{l}\text { Toxigenic } A \text {. flavus } \\
T \text {. harzianum }\end{array}$ & $\begin{array}{c}0 \\
26\end{array}$ & $\begin{array}{l}0 \\
0\end{array}$ & $\begin{array}{l}0 \\
0\end{array}$ & $\begin{array}{l}0 \\
5\end{array}$ & $\begin{array}{l}0 \\
0\end{array}$ & $\begin{array}{l}0 \\
0\end{array}$ \\
\hline $\begin{array}{l}\text { Toxigenic A. flavus vs } \\
\text { T. harzianum - not watered }\end{array}$ & $\begin{array}{l}\text { Toxigenic } A \text {. flavus } \\
\text { T. harzianum }\end{array}$ & $\begin{array}{c}0 \\
65\end{array}$ & $\begin{array}{l}0 \\
0\end{array}$ & $\begin{array}{l}0 \\
0\end{array}$ & $\begin{array}{c}0 \\
35\end{array}$ & $\begin{array}{l}0 \\
0\end{array}$ & $\begin{array}{l}0 \\
0\end{array}$ \\
\hline
\end{tabular}

*) Peanut seeds derived from the plants where the planting media were treated with various fungal inocula and time of watering 


\section{Table 7. Aflatoxin $\mathrm{B}_{1}$ content of peanut kernels at harvest time *)}

\begin{tabular}{lc}
\hline \hline \multicolumn{1}{c}{ Treatment } & Aflatoxin $\mathbf{B}_{1}$ content (ppb) \\
\hline Toxigenic $A$. flavus - watered & 32 \\
Toxigenic $A$. flavus - not watered & Not detected \\
Toxigenic $A$. flavus vs nontoxigenic $A$. flavus - watered & Not detected \\
Toxigenic $A$. flavus vs nontoxigenic $A$. flavus - not watered & Not detected \\
Toxigenic $A$. flavus vs $A$. niger - watered & Not detected \\
Toxigenic $A$. flavus vs $A$. niger - not watered & Not detected \\
Toxigenic $A$. flavus vs $T$. harzianum - watered & Not detected \\
Toxigenic $A$. flavus vs $T$. harzianum - not watered & Not detected \\
\hline
\end{tabular}

*) Peanut seeds derived from the plants where the planting media were treated with various fungal inocula and time of watering.

\section{CONCLUSIONS}

At the time of harvest, decrease in the moisture content of peanuts in the planting media not watered for 15 days before harvest was higher than those watered until harvest.

The lowest population of toxigenic A. flavus was in the planting media inoculated with the combined use of toxigenic and nontoxigenic $A$. flavus at the time of inflorescence and at the time of harvest.

Toxigenic A. flavus could invade the roots, stems and flowers of peanut plants. The lowest percentage of invasion was on the plant parts where the planting media were inoculated with the combined use of toxigenic and nontoxigenic A. flavus.

The moisture content of peanut kernels originated from plants watered until harvest was higher than those not watered for 15 days before harvest.

The population of toxigenic A. flavus in peanut kernels derived from the plants where the planting media were inoculated with the combined use of toxigenic A. flavus and each test fungi, was lower than that only inoculated with toxigenic A. flavus. It indicated that the test fungi inoculated into planting media could inhibit toxigenic $A$. flavus infection in peanut kernels.

Aflatoxin B] was only detected in peanut kernels originated from one plant where the planting medium was only inoculated with toxigenic $A$. flavus and the plant watered until harvest.

Toxigenic A. flavus infection and aflatoxin Bj production were not influenced by the planting media which were not watered for 15 days before harvest. 
Control of aflatoxigenic Aspergillus flavus in peanuts - Okky S. Dharmaputra et al.

\section{ACKNOWLEDGEMENT}

The authors gratefully acknowledge the financial support of the Government of Indonesia. Thanks are due to the Research Institute for Legumes and Tuber Crops (RILET), Malang, in providing peanut seeds var. Komodo. We also thank Ms. Shanti Saraswati, Department of Biology, Faculty of Mathematics and Natural Sciences, Bogor Agricultural University, and the technicians of the Laboratory of Pest and Disease Management, SEAMEO BIOTROP for their valuable assistance in conducting the experiment.

\section{REFERENCES}

AOAC. 1995. Natural toxins. In E. Scott (ed.). Official Methods of Analysis of Natural Poison. $6^{\text {th }}$ ed. Association of Official Analytical Chemists, Arlington. Chap. 49. p. 1-5.

BS1. 1995. Oilseeds-determination of Moisture and Volatile Matter Content. British Standard International.

Dharmaputra, O.S., A.S.R. Putri, I. Retnowati and S. Ambarwati. 2001. Soil mycobiota of peanut fields at Wonogiri regency, Central Java: their effect on the growth and aflatoxin production of Aspergillus flavus in vitro. BIOTROPIANo. 17: 3058

Dorner, J.W., R.J. Cole and P.D. Blankenship. 1998. Effect of inoculum rate of biological control agents on preharvest aflatoxin contamination of peanuts. Biological Control 12: 171-176

Dorner, J.W., R.J. Cole and D.T. Wicklow. 1999. Aflatoxin reduction in corn through field application of competitive fungi. Journal of Food Protection 62(6): 650-656

Ehrlich, K., A. Ciegler, M.A. Klich and L. Lee. 1985. Fungal competition and mycotoxin production on corn. Experimentia 41: 691 - 693 .

Johnson, L.F., E.A. Curl, J.H. Bond and H.A. Fribourg. 1960. Methods for Studying Soil Microflora-Plant Disease Relationships. Burgess Publishing Company, Minneapolis.

Johnson, L.F. and E.A. Curl. 1972. Methods for Research on the Ecology of Soil-borne Plant Pathogens. Burgess Publishing Company, Minneapolis.

Pitt, J.I., S.K.. Dyer and S. McCammon. 1991. Systemic invasion of developing peanut plants by Aspergillus flavus. Letters in Applied Microbiology 13: 16-20.

Pitt, J.I. and A.D. Hocking. 1996. Current knowledge of fungi and mycotoxins associated with food commodities in Southeast Asia. In Highley, E. and G.I. Johnson (eds). Mycotoxin Contamination in Grains. Pp. 5-10. ACIAR Technical Reports 37, Canberra.

Wicklow, D.T., B.W. Horn, O.L. Shotwell, C.W. Hesseltine and R.W. Caldwell. 1988. Fungal interference with Aspergillus flavus infection and aflatoxin contamination of maize grown in a controlled environment. Phytopathology 78: 68 - 74. 